\title{
Problems in Sentence Construction at HSSC Level in Pakistan
}

\author{
Muhammad $\operatorname{Din}^{1} \&$ Mamuna Ghani ${ }^{2}$ \\ ${ }^{1}$ Govt. Postgraduate College Burewala, Burewala, Pakistan \\ ${ }^{2}$ Chairperson Department of English, Faculty of Arts \& Islamic Learning, The Islamia University of Bahawalpur, \\ Bahawalpur, Pakistan \\ Correspondence: Muhammad Din, Govt. Postgraduate College Burewala, Pakistan. E-mail: mduaau@gmail.com
}

Received: August 7, 2017 Accepted: September 8, 2017 Online Published: October 25, 2017

doi:10.5539/ijel.v8n1p200 URL: https://doi.org/10.5539/ijel.v8n1p200

\begin{abstract}
This study entitled "Problems in the Construction of Sentence at HSSC Level in Pakistan" strives to unearth the problems faced by the students in learning sentence structure through literature and the facts regarding the role of literature as a teaching tool in teaching English as a second/foreign language with reference to the construction of sentence at Higher Secondary School Certificate (HSSC) level in Pakistan. This study also investigates how much the students learn English sentence structure through literature. To achieve the set objectives of this study, the researcher went for the quantitative research methodology. So, a questionnaire comprising of 30 items encompassing the different aspects of sentence structure was designed to collect data from 600 subjects (male/female) of HSSC (Higher Secondary School Certificate) level. The researcher has also conducted an achievement test so that a correlation might be drawn between their attitude towards "teaching English sentence structure through literature" and the score of their achievement test. The collected data were analyzed through software package (SPSS XX) which is commonly used in applied linguistics. The findings of this study explicitly reveal that the EFL learners remain unable to learn and develop both the contraction of sentence and syntactic skills when they are taught English through literature. This study recommends that the teaching of English should be application oriented and task-based strategies and activities should be resorted to by the FL educators.
\end{abstract}

Keywords: sentence construction, literature, second language, ESL learners

\section{Introduction}

All languages have syntactic structure. This means that a language does not consist of strings of words rather words group together to form phrases and phrases group together to form larger phrases and sentences. This pattern of phrase within phrase is known as hierarchical structure. The study of the ways in which words combine into such units as phrase, clause, and sentence is known as syntax. The sequences that result from these combinations are referred to as syntactic structures. The ways in which components of words are combined into words are studied in morphology. Syntax and morphology together are generally regarded as the major constituent of grammar. According to Chomsky (1972), each language has a specific relationship between sound (phonetic representation) and meaning (semantic representation). Syntactic structure bridges sound and meaning. McArthur (1992) also claims that in the recent years, some linguists have tended to abandon the vertical "layer cake" model in favor of horizontal model with a syntactic component flanked by a phonological component on one side and a semantic component on the other. Syntax has this central role because it can be regarded as the component that links sound and meaning. It can be illustrated as follows:

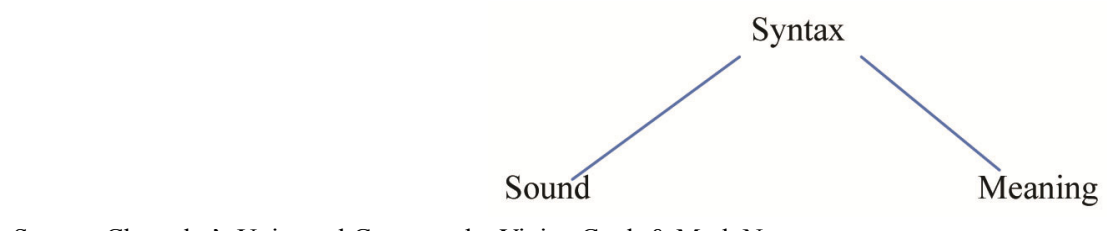

Source: Chomsky’s Universal Grammar by Vivian Cook \& Mark Newson.

The largest structural unit normally treated in grammar is called sentence. "The classical definition, that a 
sentence expresses a complete thought, dates from the first Western treatise on grammar, by Dionysius Thrax" (McArthur, 1992). Wren \& Martin (1999) define sentence as "a sentence is a set or group of words which makes complete sense". It can also be defined as a sentence is a group of words that includes a subject and a predicate and expresses a complete thought.

The problem that confronts the researcher is that teaching English through Literature does not render any positive pay off in developing and honing the EFL/ESL learners' skill of the construction of sentence. In the Pakistani context, literature seems to be inadequate and improper language teaching tool at Intermediate level. English is a compulsory subject up to Bachelors level in Pakistan but it has been observed that even after spending a lot of time in learning English, majority of school and college students are unable to write grammatically correct English. There are certain other problems and challenges which render these textbooks an inadequate teaching resource. The most glaring among them are the prescriptive syllabus, teaching methodology, provision of ready-made material and the assessment system. Moreover, the selected textbooks are not used to develop and hone all the basic language skills listening, speaking, reading and writing. For instance, the texts chosen to this end pose difficulties at grammatical, linguistic and literal level. It has also been observed that the teaching of English in Pakistan is highly ritualized. The literary texts do not include the structures and vocabulary previously learned and difficult and ambiguous structures also elude most of the learners of English language. The texts chosen to teach English through literature rarely deal with linguistic and grammatical sides. As a result, the EFL learners face the problems like mixed construction, subject-verb agreement, misplaced modifiers, split infinitives and the lack of parallel constructions. Apart from these afore-stated problems, the ESL/EFL learners also encounter the problems like wrong start, wrong use of tense, wrong time sequence of time and wrong use of adjective, prepositional and adverb phrases in their construction of sentences. (See Appendix I)

\subsection{Significance of English}

English has become an international language or an international lingua franca. It has achieved such a status as is recognized by every country across the world. In Pakistan, English occupies a place of honor and prestige among the languages spoken here. In recent times, owing to the remarkable success of the English-speaking nations in the fields of industry and politics, the people, governments, and institutions have steered their focus and interest towards this language. It has generally been observed that strong language competence renders students good pedestal and they get entry into higher institutions as the learning of English language wields so much intense importance in Pakistan in the present scenario. English has also become the symbol of education and an elite status in the Pakistani society and has become the language of media, science, technology and a means of inter-national as well as intra-national communication. Ghani (2003) styles this language "a gateway to success" in Pakistan. Akram \& Mehmood (2007) have analyzed the factors which motivate the Pakistani students to go for the learning of English language. They claim that the motivational factors like studies abroad, greater job opportunities, social or missionary aspirations, better economic prospects and academic ends make them learn this language.

\subsection{Teaching of English as a Second/Foreign Language in Pakistan}

English is a compulsory subject up to graduation level in Pakistan but it has been observed that even after spending a lot of time in learning English, majority of school and college students are unable to write grammatically correct English. It has been observed that the teaching of English in Pakistan, specifically in state-run schools and colleges, is highly ritualized. Seldom do the students focus on learning English when they are mentally obsessed in learning texts for the sake of its reproduction. The reproduction of set texts and the provision of memorized written answers to questions about those texts mean that the teaching of English neglects speaking, listening and critical reading which are termed as the integral features of language competence. Akram \& Mehmood (2007) have also analyzed and enumerated some of the problems and challenges which are being faced in teaching English as a foreign language in Pakistan. A very pertinent and relevant issue regarding the teaching of English as a foreign language in Pakistan has been raised by them is that of medium i.e., literature. They seem to be convinced that this medium of teaching English language is inadequate to impart the required competence among the learners of this language.

\subsection{Objectives}

* To highlight the most important syntactic problems faced by the HSSC ESL learners.

* To analyze the role of literature in enhancing the ESL learners' syntactic competence. 
* To recommend some suggestions to get the maximum from the literature taught at intermediate level for the development of ESL/EFL learners' sentence construction skill.

\subsection{Research Questions}

- What are the most important syntactic problems faced by the HSSC ESL learners?

* What is the role of literature in enhancing the ESL learners' syntactic competence?

* What are the suggestions to get the maximum from the literature taught at intermediate level for the development of ESL/EFL learners' sentence construction skill?

\section{Literature Review}

Haider (2014) has explored those organizational problems which the Pakistani students face in ESL writing. These problems include overused coordinate sentences and misused topic sentences. This study also reports that the Pakistani students face problems in the use of cataphoric and anaphoric references, ellipsis, substitution and genre related organizational ties. Lack of motivation and self-confidence and writing anxiety also pose a challenge to the Pakistani ESL learners. The literature produced by Pakistani writers can prove more effective and productive for language learning as it does not pose the problem of contextualization. While advocating the use of Pakistani literature for English language instruction, the linguists maintain that stylistic-based perception and critical perception can be enhanced by integrating language with literature.

Adeel \& Sajid (2014) have studied the organizational problems faced by the Pakistani student writers. By using questionnaire and viva voce questions, the researchers have reached the conclusion that these students face the difficulties in the use of the cohesive devices like substitution, ellipsis, conjunction and lexical cohesion.

Ross (2015) has investigated the challenges faced by the Arab students in writing a well-developed paragraph in English. He maintains that the students must strike a balance among the issues like content, organization, purpose, audience and vocabulary. Ross (2015) has also found out that the students write such clauses as neither follow punctuation system nor the sentence structure. The researcher further claims that the simple, compound and complex sentences pose another difficulty for the ESL learners.

Demerezen (2012) has analysed the problem causing structures of simple sentences for the Turkish University students. The researcher has discussed the basic elements of a simple sentence and its different patterns. According to the study, an extended simple sentence i.e., with double or triple structures in subjects, verbs and objects is a problem causing area for the Turkish students. The researcher also claims that double predicates in a simple sentence also confuse the students. The main focus of this study is the overlooked and neglected structures which the researcher calls the simple sentence with the extended phrasal elements.

Kunwar (2013) lays stress on creating opportunities for the interaction of the ESL learners with quality literature. While reflecting on the practices being carried on in Indian classrooms, the researcher presents a very saddening side of the picture regarding the use of literature in the language classroom. These facts also come true in the Pakistani context, too. While reflecting on the prevalent practice in the Indian context, Kunwar (2013) quite aptly maintains that a highly mechanical and conventional approach is adopted towards literature in the language classroom, teacher reads and explains each and every line the text, students are expected to scan the text so as to get information for the sake of the exam and they are expected to cram the answers to the questions given at the end of a lesson. Thus the basic aspects of language skills and language areas are neither dealt with nor developed because of this.

\section{Research Methodology}

This study is primarily quantitative in nature. So, the researcher has gone for the quantitative research methodology. According to Dornyei (2011), "quantitative research involves data collection procedures that result primarily in numerical data which is then analyzed primarily by statistical methods." Typical example: survey research using a questionnaire, analyzed by statistical software such as SPSS. Appendix I contains a specimen of a few problems which are faced by the ESL/EFL learners in learning sentence construction through literature.

\subsection{Participants and Research Tools}

The subjects of the present study are 600 (male and female) students of intermediate level of different colleges of Pakistan. For the administration of the questionnaire, such participants were selected as could prove the representative of the population of the study. For instance, the subjects of this study are the students of the intermediate class, part II. The research instrument consists of thirty items and all the questionnaire items of this research instrument are close-ended on Likert scale from "strongly agree" to "strongly disagree". 


\subsection{Achievement Test}

In order to draw a correlation between the participants' attitude towards teaching sentence structure through literature and their achievement test score, the researcher has conducted an achievement test on the pattern of "TOEIC Writing Test" in accordance with the context of the Pakistani ESL/EFL learners. This achievement test primarily consisted of three questions. The first question was comprised of five pictures in which below every picture were two words which the subjects were to use in their sentence to describe the picture. They might change the form of the words to suit the grammar of their sentence. The second question consisted of two Respond-to-a-Written questions and the third question was one "Write-an-Opinion-Essay" in which the subjects were to write an essay to state, explain and support their opinion on an issue. The achievement test carried 25 marks. In order to convert the each respondent's obtained score into percentage, the researcher multiplied that score to the percentile 08 . The response of the subjects was scored on the parameters given as follows:

$>$ The appropriate use of grammar

$>$ The relevance of the sentence to the picture

$>$ The quality and variety of sentences

$>$ Vocabulary

$>$ Organization

\section{Results and Discussion}

Table 1. ESL learners' attitude towards teaching sentence structure through literature

\begin{tabular}{|c|c|c|c|c|c|c|c|c|}
\hline S. No. & Questionnaire Items & SA & $\mathrm{A}$ & $\mathrm{N}$ & DA & SDA & Mean & $\mathrm{SD}$ \\
\hline 1 & $\begin{array}{l}\text { The literature I am taught does not help me } \\
\text { understand all about noun. }\end{array}$ & 54 & 318 & 4 & 200 & 24 & 3.3 & 1.139 \\
\hline 2 & Count and non-count nouns cause problem to me. & 46 & 315 & 25 & 181 & 33 & 3.27 & 1.133 \\
\hline 3 & $\begin{array}{l}\text { I do not learn the change of pronouns in English } \\
\text { class. }\end{array}$ & 53 & 288 & 14 & 194 & 51 & 3.16 & 1.213 \\
\hline 4 & $\begin{array}{l}\text { I cannot easily make a distinction between adjective } \\
\text { and adverb after going through the lessons of my } \\
\text { text book. }\end{array}$ & 73 & 311 & 11 & 177 & 28 & 3.37 & 1.162 \\
\hline 5 & $\begin{array}{l}\text { The comprehension and use of adverbs create } \\
\text { problem for me. }\end{array}$ & 86 & 369 & 5 & 114 & 26 & 3.63 & 1.078 \\
\hline 6 & $\begin{array}{l}\text { With the help of my text books, I learn about the } \\
\text { conjunctions and their correct use. }\end{array}$ & 56 & 220 & 18 & 253 & 53 & 2.95 & 1.231 \\
\hline 7 & $\begin{array}{l}\text { I do not learn thoroughly the use of articles after } \\
\text { having gone through the book. }\end{array}$ & 78 & 317 & 8 & 177 & 20 & 3.43 & 1.139 \\
\hline 8 & $\begin{array}{l}\text { Prepositions and their use remain no longer a } \\
\text { problem for me when I have learnt my lesson. }\end{array}$ & 47 & 203 & 6 & 265 & 79 & 2.79 & 1.256 \\
\hline 9 & $\begin{array}{l}\text { I buy a helping book to comprehend the } \\
\text { grammatical aspects of language. }\end{array}$ & 242 & 314 & 2 & 32 & 10 & 4.24 & .844 \\
\hline 10 & $\begin{array}{l}\text { I do not learn the correct usage of the tenses while } \\
\text { reading the text books. }\end{array}$ & 119 & 326 & 3 & 127 & 25 & 3.64 & 1.141 \\
\hline 11 & $\begin{array}{l}\text { I face no difficulty in maintaining subject-verb } \\
\text { agreement after having gone through my text books. }\end{array}$ & 19 & 131 & 8 & 318 & 124 & 2.34 & 1.125 \\
\hline 12 & $\begin{array}{l}\text { I also learn the auxiliary verbs and their usage with } \\
\text { the help of my text books. }\end{array}$ & 82 & 343 & 7 & 148 & 20 & 3.53 & 1.103 \\
\hline 13 & I face problem in the use of causative verbs. & 169 & 315 & 22 & 77 & 17 & 3.9 & 1.039 \\
\hline 14 & $\begin{array}{l}\text { I always answer the question in the same tense in } \\
\text { which it is asked. }\end{array}$ & 67 & 197 & 7 & 261 & 68 & 2.89 & 1.286 \\
\hline 15 & $\begin{array}{l}\text { While reading the text book, I do not learn how to } \\
\text { change the narration. }\end{array}$ & 137 & 336 & 8 & 104 & 15 & 3.79 & 1.058 \\
\hline 16 & $\begin{array}{l}\text { I experience difficulty in changing the voice of a } \\
\text { sentence. }\end{array}$ & 108 & 327 & 11 & 129 & 25 & 3.61 & 1.132 \\
\hline 17 & $\begin{array}{l}\text { In English class, I do not learn how auxiliary verbs } \\
\text { are used in making interrogative sentences. }\end{array}$ & 55 & 281 & 8 & 207 & 49 & 3.14 & 1.22 \\
\hline 18 & Tag questions are taught in English class. & 136 & 269 & 12 & 151 & 32 & 3.54 & 1.236 \\
\hline 19 & $\begin{array}{l}\text { I am not familiar with the concept of ellipsis in } \\
\text { language. }\end{array}$ & 115 & 264 & 15 & 175 & 31 & 3.43 & 1.235 \\
\hline
\end{tabular}




\begin{tabular}{|c|c|c|c|c|c|c|c|c|}
\hline 20 & $\begin{array}{l}\text { The prosodic features are also focused during my } \\
\text { studying a piece of text. }\end{array}$ & 59 & 152 & 11 & 257 & 121 & 2.62 & 1.319 \\
\hline 21 & $\begin{array}{l}\text { While reading text, I do not become able to } \\
\text { recognize the different kinds of phrases. }\end{array}$ & 120 & 362 & 10 & 94 & 14 & 3.8 & 1.007 \\
\hline 22 & $\begin{array}{l}\text { I can comprehend and use those phrasal verbs which } \\
\text { I have learnt from my text books. }\end{array}$ & 21 & 171 & 17 & 296 & 95 & 2.55 & 1.161 \\
\hline 23 & $\begin{array}{l}\text { I do not fully understand the constituents and kinds } \\
\text { of a clause used in the text. }\end{array}$ & 105 & 341 & 13 & 125 & 16 & 3.66 & 1.074 \\
\hline 24 & $\begin{array}{l}\text { I cannot learn about the structure of sentence in } \\
\text { English class. }\end{array}$ & 95 & 305 & 7 & 167 & 26 & 3.46 & 1.176 \\
\hline 25 & $\begin{array}{l}\text { I can easily determine whether the sentence is in } \\
\text { indicative or interrogative mood after I have learnt } \\
\text { my lesson well. }\end{array}$ & 92 & 360 & 5 & 110 & 33 & 3.61 & 1.115 \\
\hline 26 & $\begin{array}{l}\text { Text books do not supply essential information } \\
\text { about grammatical form and structures. }\end{array}$ & 143 & 318 & 13 & 100 & 26 & 3.75 & 1.122 \\
\hline 27 & $\begin{array}{l}\text { The literature that is taught describes and } \\
\text { exemplifies both types of language use i.e. spoken } \\
\text { and written. }\end{array}$ & 28 & 124 & 9 & 289 & 150 & 2.32 & 1.189 \\
\hline 28 & $\begin{array}{l}\text { I face a problem in the construction of conditional } \\
\text { sentences. }\end{array}$ & 91 & 376 & 10 & 97 & 26 & 3.68 & 1.051 \\
\hline 29 & $\begin{array}{l}\text { I find myself at ease in rendering a passage from } \\
\text { Urdu into English and vice versa. }\end{array}$ & 41 & 119 & 4 & 297 & 139 & 2.38 & 1.228 \\
\hline 30 & $\begin{array}{l}\text { While reading text, I do not learn about the simple, } \\
\text { complex and compound sentences. }\end{array}$ & 124 & 338 & 9 & 108 & 21 & 3.73 & 1.088 \\
\hline
\end{tabular}

The results of the present study show that the learning, practice and use of the grammatical aspects are the most neglected area in the teaching of English through literature. The parts of speech and their usage are rarely discussed, practiced and tested in the language classroom as the teaching of English through literature or text books does not provide the ESL learners of the intermediate level any chance to learn the grammar and the grammatical aspects of the target language. It is because that GTM excludes the learning of grammatical aspects of the language. In this respect, these findings of the present study relate to those of Sakthivel \& Kavidha (2010) who lament that language acquisition is purely theoretical not application-oriented.

It has also been found that $64 \%$ of the respondents can't make a distinction between adjective and adverb whereas $75.8 \%$ ESL learners face problems in the use of adverbs. The level of the ESL learners' grammatical competence can be estimated from the fact that $92.6 \%$ students buy guide books to learn the grammar and the grammatical aspects of English language. Moreover, $73.7 \%$ EFL learners face the problem of subject-verb agreement when they learn language through textbooks and $81 \%$ of them face problem in the use of causative verbs. As far as the change of narration is concerned, $78.8 \%$ do not find themselves able to do this.

Regarding the role literature in teaching the grammar and grammatical aspects of the target language, the findings of this study are also seconded by those of the study conducted by Mckay (1982) who expresses the same reservation regarding the role of literature in the teaching of grammar. In his study, he maintains that literature lacks contribution to the teaching of grammar. This study finds out that the textbooks used as a teaching tool at the intermediate level to teach the grammar of the target language do not enable the ESL learners to get a comprehensive command over it. These findings of the present study also relate to those of the study conducted by Cruz (2010) in which he claims that the literature included in the textbooks for the pedagogic ends provides an "artificial grammar". With the help of such type of grammar, the EFL learners learn a "nowhere English". Consequently, the ESL learners remain unable to enjoy communicative competence in the real sense. Cruz (2010) calls this level of these EFL learners' language competence a "survival level" because they do not get any exposure to "language in use" in the language classroom and they are penned in an atmosphere of "static nature".

It has also been found out that the use of literature as a teaching tool plays little role to further the ESL learners' communicative competence. The present study relates to Ansari's (2013) in which he propounds the same thing while rounding off his study that the literature taught to the ESL learners is not supported with grammar-oriented exercises which can be done in the language classroom to practice the grammatical aspects of the language. Ansari (2013) believes that the current practices in teaching literature to the EFL learners seem to encourage content-based and memory-oriented study of literature. 
The present study has tried to investigate the problems faced by EFL learners in connection with their learning sentence structure through literature. It has also been strived to get insight into the EFL learners' attitude towards their learning sentence structure in the language class. This study finds out the textbooks do not provide essential information about grammatical form and structure. The EFL learners remain unable to learn different kinds of phrases and their use in their composition. These findings of the present study relate to those of the study conducted by Bilal et al. (2013). It also presents the same picture as it has also brought to light those factors which cause problems for the FL educators in honing the EFL learners' writing skills. They call it a strenuous task which demands the development of the EFL learners' both linguistic and communicative competence. They have also found out the EFL learners remain unable to develop their writing skill because of the teachers' using and following the traditional approach. The same issue has been raised by Khatib \& Mellati (2012) when they maintain that the textbooks taught by the FL educators have no appeal for the students and are loaded with such grammar exercises as have nothing to do with the EFL learners' interests and lives. The findings of the present study also highlight that old and traditional method of teaching language through literature is mere product-centered. These findings are supported by the study conducted by Eastwood (2005) in which he explicates that looking at the examples of English language can be more effective and useful than mere reading about them. He further claims that the EFL learners should know how English language works rather to memorize the "rules". The author very aptly points out that "the important thing is the language itself". Eastwood (2005) also claims that "active learning will help you more than passive reading, so it is important to do the exercises and to check your answer".

This study also investigates the problems owing to which the EFL learners fail to achieve grammatical correctness in the target language. For instance, the present study finds out that the problem of subject-verb agreement remains unaddressed in teaching English through literature. This finding of the present study is also seconded by a case study conducted by Nayan (2009) who has found out that after spending almost 12 years, the EFL learners remain unable to maintain subject-verb agreement in their expressions. In the same way, Shuib (1991) also finds out that the subject-verb agreement is one of the most challenging problems which are faced by the Malaysian EFL learners. Moreover, Dorn (2000) seems to be convinced of the significance of subject-verb agreement for mastering the grammar of the target language. Likewise, Aghagolzade \& Tajabadi (2012) have also strived to dig out the causes behind this pitfall faced by the EFL learners. According to them, the language used in poetry and prose is deviated from the standards, conventions and rules and has manipulated grammar and lexis which is not the presentation of the real-life "language in use" (Cruz, 2010).

When we have a look at the aggregate response extended by the subjects of this study, we find out that $54.69 \%$ of the respondents have agreed while $19.19 \%$ respondents have strongly agreed that they remain unable to get insight into and the practice of different aspects of English sentence structure. For instance, the EFL learners remain unaware of the different elements of sentence and its types. But it is interesting to note that $75.3 \%$ of the respondents claim that after learning their lesson well, they can determine whether the sentence is in indicative or interrogative mood.

This study has found out that $73.88 \%$ respondents show their agreement that sentence structure and its different aspects are not focused during their being taught English through literature. For the syntactical aspects of the target language remain untapped in the teaching of English through literature at intermediate level. For instance, $77.9 \%$ of the respondents claim that they face problem in the construction of conditional sentences. In the same way, $72.7 \%$ subjects of the study respond that they do not feel themselves at ease in rendering a passage from Urdu into English and vice versa. It has also been found out that $77 \%$ of the respondents do not learn about simple, compound and complex sentences in the language class. All these facts reveal that syntax and syntactical aspects of the target language are the most ignored area of language teaching and learning through literature. The reason behind this sad plight is that the ESL learners do not get any chance to personalize the writing activities when they are kept engaged in merely grammar tasks and pattern practices. The same opinion has been expressed by Mashori \& Lal (2011) who maintain that writing a grammatically correct sentence does not mean the ability to write a convincing and logical essay because this skill demands much more than this.

The same findings have also been reached at by Leki \& Carson (1994) who opine that the mastery of syntax and written grammar are two distinct features as it involves the acquisition of the acceptable English rhetoric. Another study conducted by Bhatia (1999) and Boshar (1998) also propounds the same view that training and practice are the major requisites for the creation of the "unified whole". The same opinion has been shared by Swales \& Feak (1994) when they suggest that apart from teaching textbooks and the literature embodied in them, training and practice are must for developing the EFL learners' writing skill. 
Table 2. Correlation between achievement test and ESL learners' attitude towards teaching sentence structure through literature

\begin{tabular}{lll}
\hline & Sentence Structure & Achievement Test \\
\hline Pearson Correlation & 1 & -.078 \\
Sig.(2-tailed) & & .058 \\
$\mathrm{~N}$ & & 600 \\
\hline
\end{tabular}

The above results indicate that the correlation coefficient for achievement test and sentence structure is negative and is not significant. This implies that the correlation is not statistically significant at all. It also reveals that the attitude of the ESL/EFL learners and their performance in learning the construction of sentence structure through literature correspond each other very much. Their language proficiency is dissatisfactory i.e., they have not shown any outstanding performance. The possible reasons behind this can be sought in the fact that while their being taught the construction of sentence structure through literature the ESL learners are neither given chance for producing their own structures nor any strategy for mastering them. In addition to this, the EL educators do not encourage the ESL/EFL learners to study with their peer groups for generating ideas so that it may have a positive effect on their skill of producing grammatically correct structures. Above all this, the motivating factors involved in the construction of sentence structures, like observation, thinking, exploration, innovation, knowledge and communicative strategies are not fostered in the English language classroom.

Table 3. Independent sample t-test (gender, location \& medium)

\begin{tabular}{|c|c|c|c|c|}
\hline Variable & & & Mean & $\mathrm{SD}$ \\
\hline \multirow[t]{6}{*}{ Sent. Structure } & Gender & Male $(\mathrm{N}=304)$ & 53.15 & 27.28 \\
\hline & & Female $(\mathrm{N}=296)$ & 68.13 & 36.08 \\
\hline & Location & Urban $(\mathrm{N}=305)$ & 61.27 & 32.84 \\
\hline & & Rural $(\mathrm{N}=295)$ & 59.79 & 32.73 \\
\hline & Medium & English $(\mathrm{N}=303)$ & 63.57 & 31.21 \\
\hline & & Urdu $(\mathrm{N}=297)$ & 57.45 & 34.05 \\
\hline
\end{tabular}

An Independent-Samples T Test was run to find out the relationship of sentence structure with gender, location and medium. The first independent-samples $T$ test was run on the mean score of the sentence structure and gender in order to test the relationship between male and female students with reference to their learning sentence structure through literature. Table 3 shows that the difference in the mean score between the male and female students is very significant i.e., 14.98. It shows that female learners outclass the male learners in the process of learning sentence structure through literature. Table 3 shows that there is very little difference in the mean score and standard deviation with respect to the variables and the location of the students. This analysis proves that there is no relationship between rural and urban students with reference to their learning sentence structure through literature. A difference of 6.12 has been noted in the mean score between the variables and the medium of instruction i.e., English and Urdu. This shows that there is some relationship between medium of instruction (Urdu/English).

Table 4. Results of independent sample t-test (gender, location \& medium)

\begin{tabular}{llllllll}
\hline Achievement Test & & Mean & SD & Std.E.M. & TValue & Sig. & E.Size \\
\hline Gender & Male $(\mathrm{N}=304)$ & 53.15 & 27.28 & 1.56 & -5.745 & .000 & -.228 \\
& Female $(\mathrm{N}=296)$ & 68.13 & 36.02 & 2.09 & & & \\
\hline Location & Urban $(\mathrm{N}=305)$ & 61.27 & 32.84 & 1.88 & .551 & .582 & .225 \\
& Rural $(\mathrm{N}=295)$ & 59.79 & 32.73 & 1.90 & & & \\
\hline Medium & English $(\mathrm{N}=303)$ & 63.57 & 31.21 & 1.79 & 2.296 & .022 & .093 \\
& Urdu $(\mathrm{N}=297)$ & 57.45 & 34.05 & 1.97 & & & \\
\hline
\end{tabular}

Table 4 shows that the female students' mean score in the achievement test is significantly higher than the male students'. The reason behind this difference is quite clear that the female students have more serious approach towards their assignments than the male students. Table 4 shows a slight difference in the mean score of the urban and rural students. The mean score of English medium students in the achievement test falls at 63.57 whereas Urdu medium students' score is 57.45. Table 4 shows the difference of 2.296 in the t-value between the 
achievement test and the medium of instruction. This analysis highlights the fact that the students with English medium background outclass those students whose medium of instruction is Urdu.

\section{Conclusion}

This study has reached the conclusion that the ESL/EFL learners face myriads of problems related to sentence construction and the literature taught to them does not render any pay-off in enhancing and honing their skill of sentence construction. One of the most important reasons behind this problem is that the ESL/EFL learners go through the literature just for the sake of scoring maximum marks in the examination and to this end they resort to the helping books and ready-made material available in the market. Thus, they do not encounter any such activities in the language class which can motivate them to do sentence construction drills and exercises on their own or under the FL educator's supervision. Apart from all this, the text books which have been included in the syllabus as teaching tools do not have such exercises at the end of the lessons as can make the ESL learners develop their skill of sentence structure. For instance, the language learners seldom get the chance of doing the practice of constructing simple, compound or complex sentences after reading the lesson. Nor do the language learners get the chance of practicing subject-verb agreement in the class after completing the lesson.

\section{Suggestions}

Keeping in view the linguistic needs of the Pakistani EFL learners of intermediate level, this study gives some recommendations which have been given as follows:

$>$ The existing teaching tool for English as foreign language needs to be revisited as the rapidly changing modern world requires the EFL learners have competence in English language because literature cannot be styled an adequate teaching vehicle which can cater to the demand of language competence.

$>$ The use of guide books should be discouraged so that the EFL learners can develop their sentence construction skills instead of cramming.

$>$ The FL educators should design such activities as can make the EFL learners go through the text books for developing their sentence construction skill not for efferent reading.

$>$ Drills and exercises regarding English parsing and analysis should also be in the lesson plan.

\section{Reference}

Aghagolzadeh, F., \& Tajabadi, F. (2012). A Debate on Literature as a Teaching Material in FLT. Journal of Language Teaching and Research, 3(1), 205-210.

Akram \& Mehmood (2009). The Status and Teaching of English in Pakistan; Language in India: Strength for Today and Bright Hope for Tomorrow, 7(12).

Ansari, M. S. (2013). Teaching Language through Literature in ESL/EFL Classes: A Critical Study in Utilitarian Perspectives. International Journal of English and Education, 2(3).

Aqeel, R. M., \& Sajid, M. A. (2014). A Study of Organizational Problems Faced by Pakistani Student Writers. International Journal of Science and Research (IJSR), 3(11), 258-261.

Bhatia, V. K. (1990). Intgrating Products, Processes, Purposes, and Participants in Professional Writing. In C. N. Candlin \& K. Hyland (Eds.), Writing: texts, processes, and practices (pp. 21-30). London: Longman.

Bilal et al. (2013). Investigating the Problems Faced by the Teachers in Developing English Writing Skills. Asian Journal of Social Sciences \& Humanities, 2(3).

Bosher, S. (1998). The Composing Processes of Southeast Asian Writers at the Post-secondary Level: An Exploratory Study. Journal of Second Language Writing, 7, 205-240.

Chomsky, N. (1972a). Language and Mind (enlarged edition). New York: Harcourt Brace Jovanovich.

Cruz, J. H. R. (2010). The Role of Literature and Culture in English Language Teaching. Retrieved from http://www.relinguistica.aza.uam.mx/no007/no07 art09.html

Demirezen, M. (2012). An Analysis of Problem-Causing Structures of Simple Sentences for Turkish University Students. International Journal of Humanities and Social Science, 2(3), 136-146.

Dorn, D. (2000). Building Essays: A Reader Centered Writing Guide. New Jersey: Prentice Hall.

Dornyei, Z. (2011). Research Methods in Applied Linguistics: Qualitative, Quantitative and Mixed Methodologies. Oxford University Press: Great Clarendon Street Oxford OX 2 6DP.

Eastwood, J. (2005). Oxford Practice Grammar (2nd ed.). Oxford: Oxford University Press. 
Ghani, M. (2003). The Status and Position of English Language in Pakistan. Journal of Social Sciences and Humanities, $1(1)$.

Haider, A. G. (2014). An Exploratory Study of Organizational Problems Faced by Student Writers with Learning Difficulties in EFL Writing. International Journal of English and Education, 3(1), 124-145.

Khatib, M., \&Mellati, M. (2012). Literature and Young Learner in an EFL Situation. Journal of Comparative Literature and Culture (JCLC), 18, 1(1).

Kunwar, N. (2013). Literature in Classrooms: Practices and Reflection; FORTELL January, 26, 20-22.

Leki, I., \& Carson, J. G. (1994). Students' Perceptions of EAP Writing Instruction and Writing Needs across the Disciplines. TESOL Quarterly, 28, 81-101.

Mashori, G. M., \& Lal, C. (2011). Developing a Teaching Program for the Students of English with Low Ability in Writing. Australian Journal of Basic and Applied Sciences, 5(5), 1119-1127.

McArthur, T. (1992). The Oxford Companion to the English Language. New York: Oxford University Press Inc.

McKay, S. (1982). Literature in the ESL Classroom. TESOL Quarterly, 16(4), 529-536.

Nayan, S. (2009). A Study of Subject-Verb Agreement: From Novice Writers to Expert Writers. International Education Studies, 2(3).

Sakthivel, V., \& Kavidha, N. (2010). Is Literature a Viable Medium for ESL Acquisition? Language In India: Strength for Today and Bright Hope for Tomorrow, 10(1).

Shuib, S. (1991). An analysis of Malaysian learners' English Agreement Errors. University of Essex.

Wren, P. C., \& Martin, H. (n. d.). High School English Grammar and Composition. Ram Nagar, New Dehli: S. Chand and Company LTD.

\section{Appendix I}

(1) Wrong Start

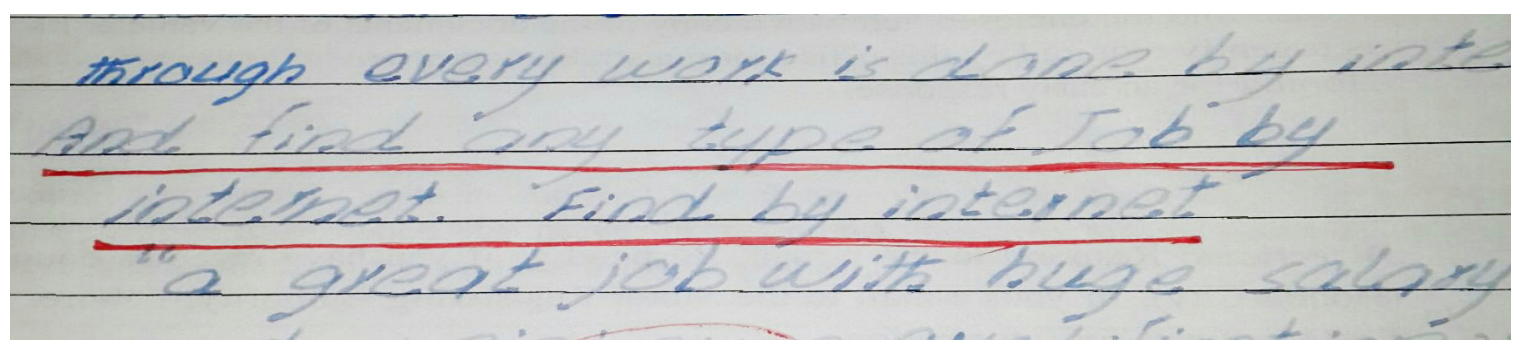

(2) Wrong Use of Tense Sequence

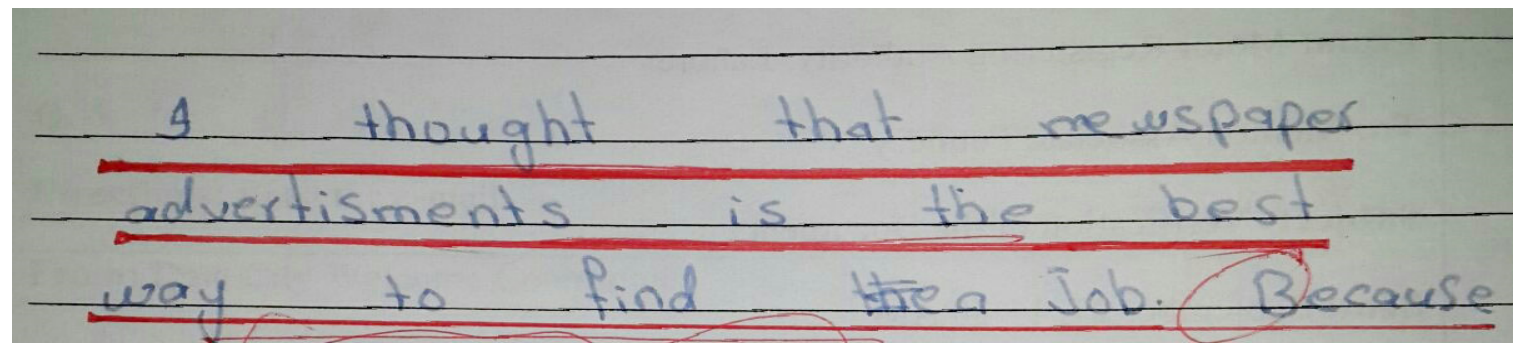

(3) Wrong Use of Tense

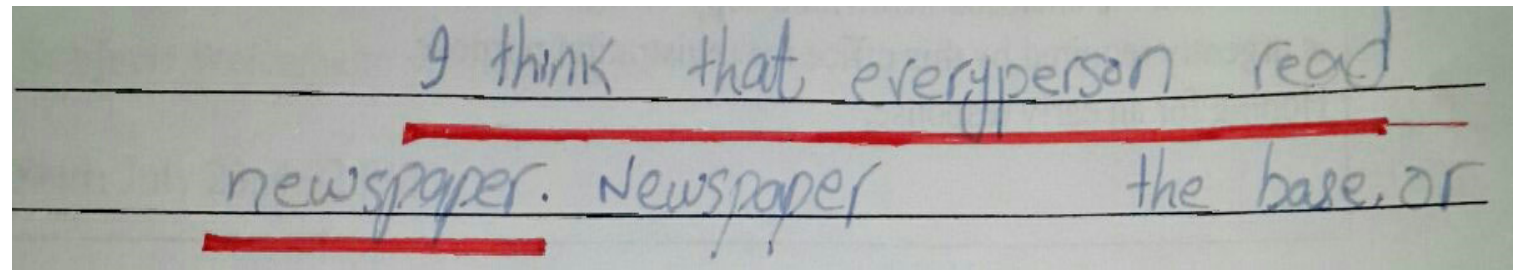


(4) Tenseless Sentence

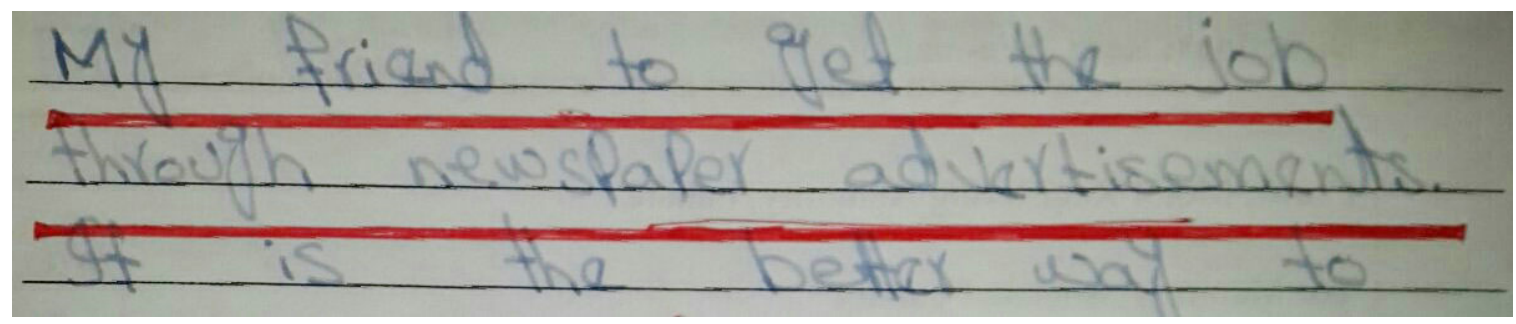

\section{(5) Lacks Time Sequence}

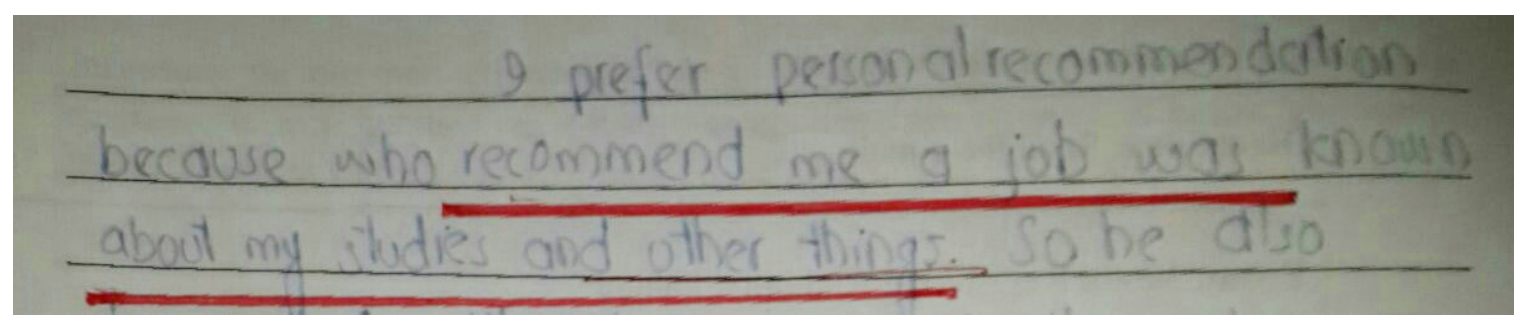

(6) Lacks Time Sequence

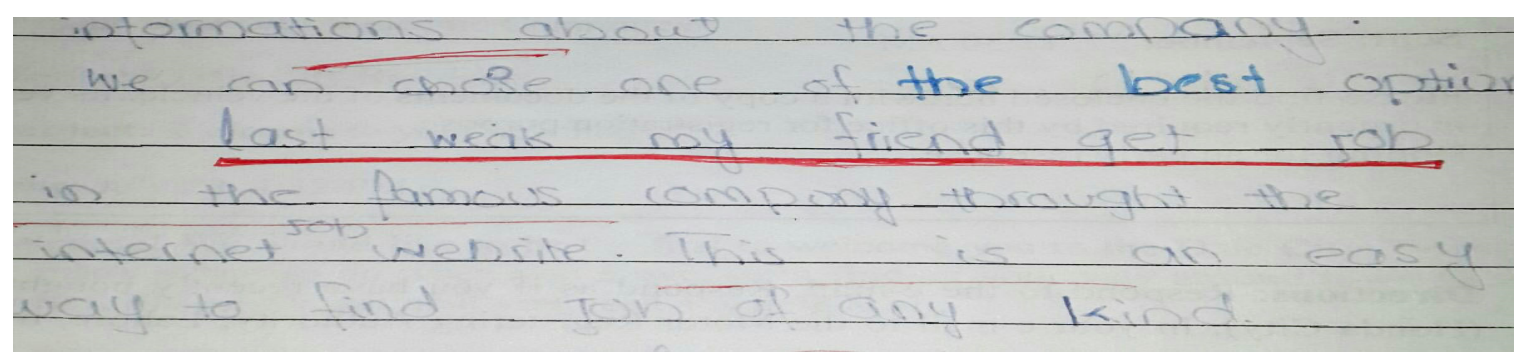

\section{(7) Wrong Subject-Verb Agreement}

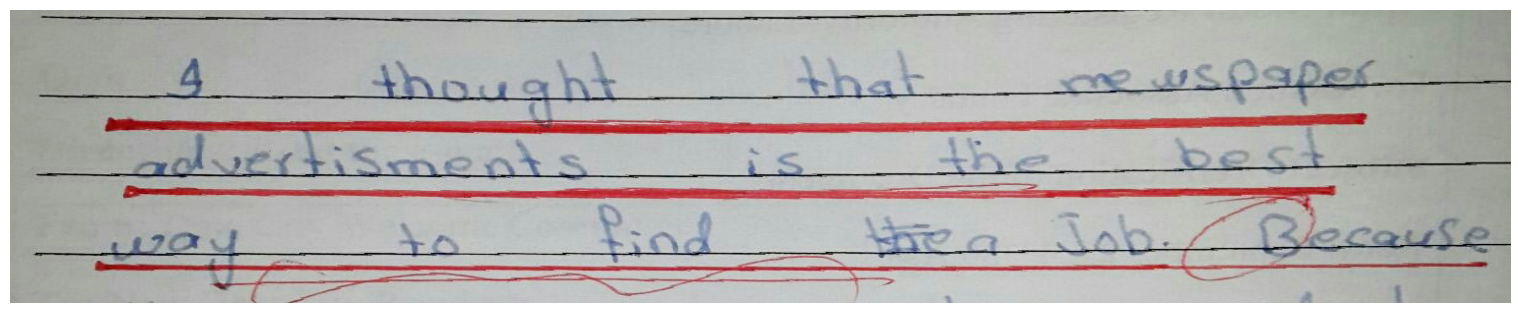

(8) Wrong Subject-Verb Agreement

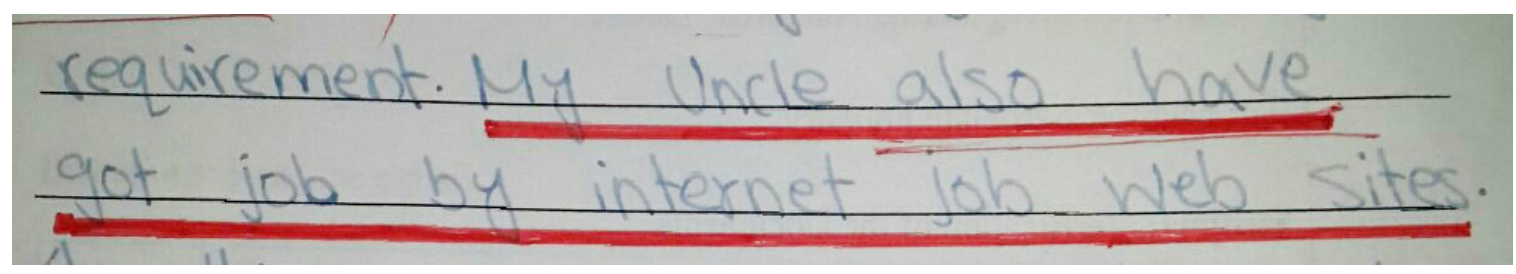

(9) Wrong Use of Auxiliary Verb

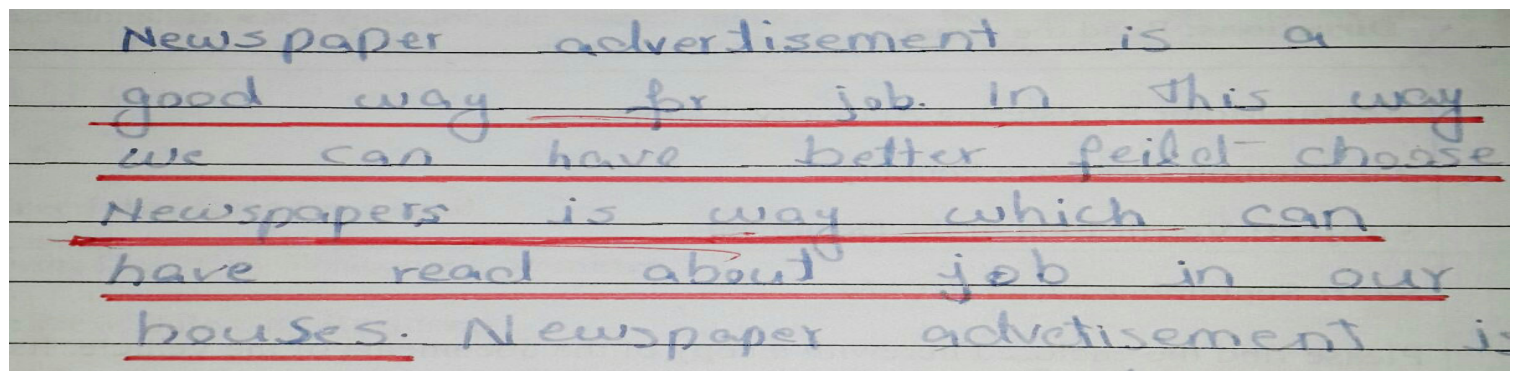


(10) Wrong Use of Adjective Phrase

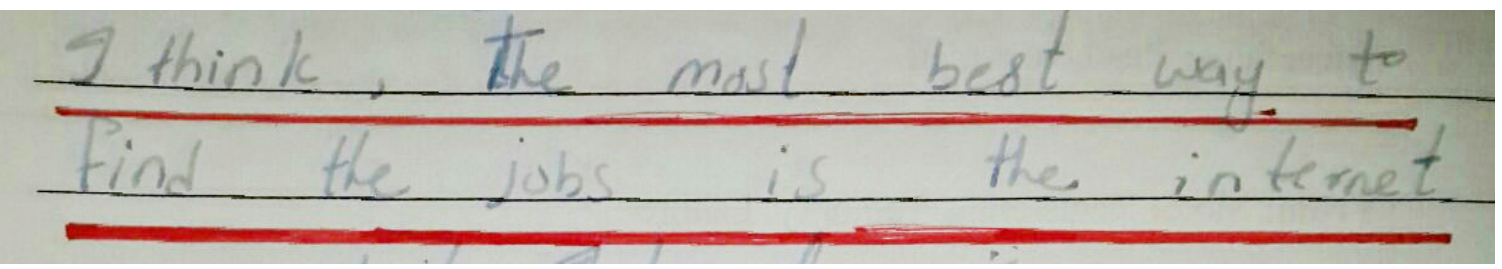

(11) Wrong Use of Prepositional Phrase

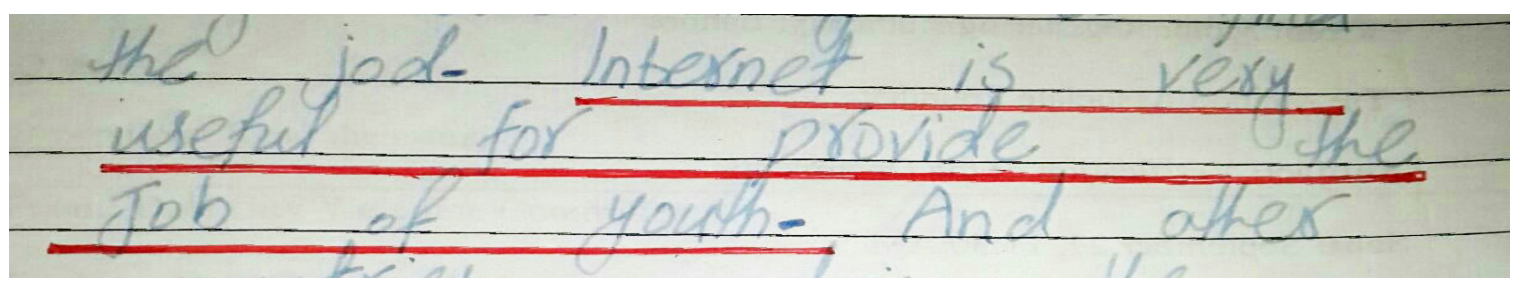

(12) Missing Appropriate Verb

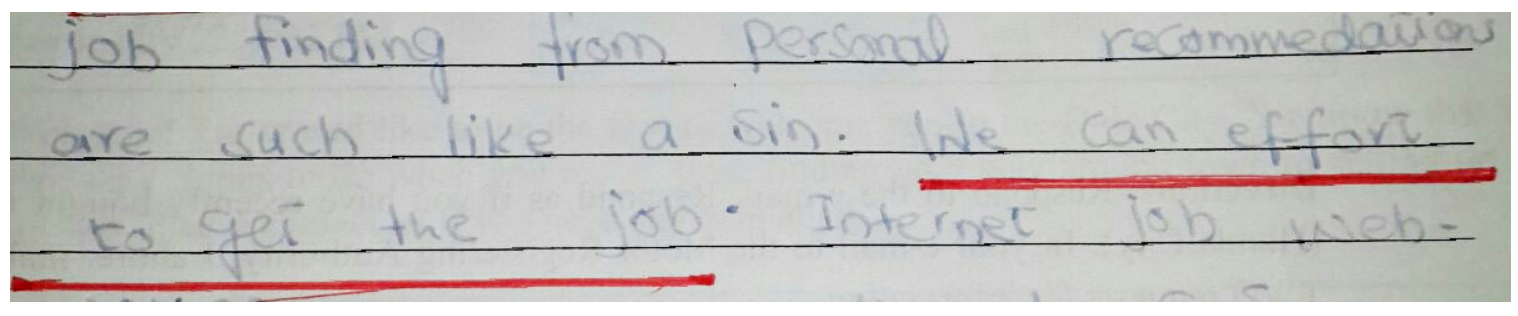

(13) Wrong Use of Conjunction

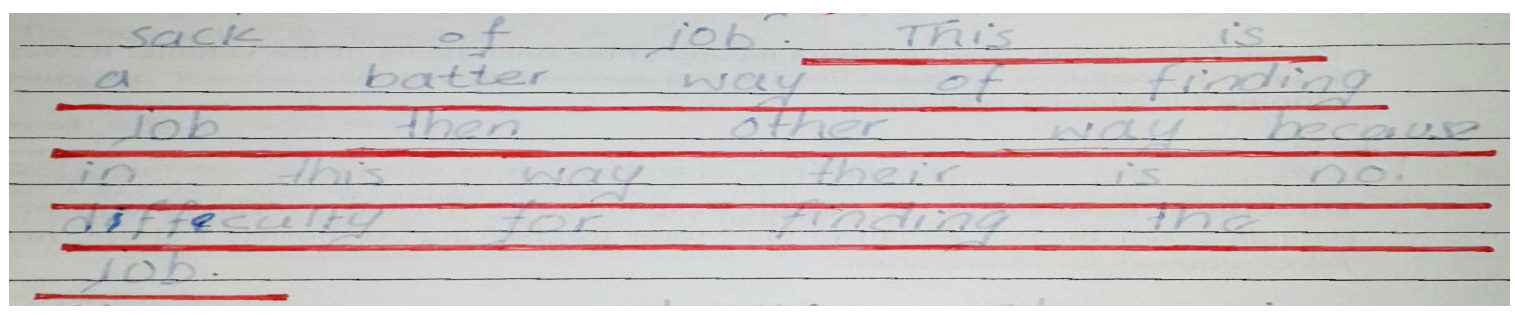

(14) Wrong Use of Infinitive

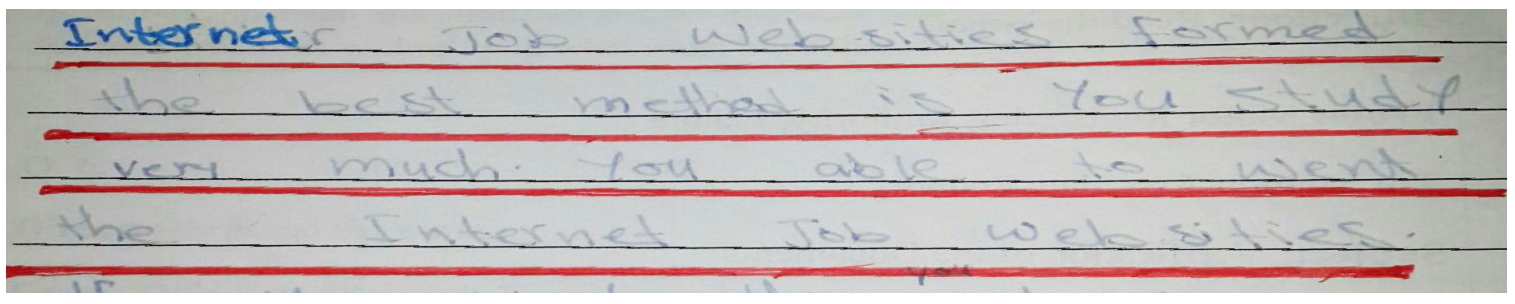

(15) Wrong Use of Infinitive

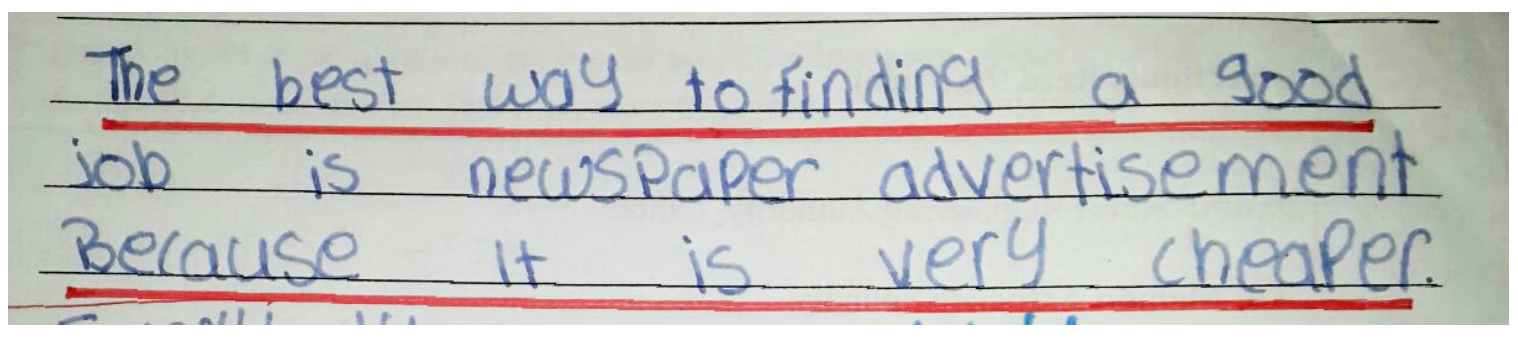


(16) Splitting Subordinate Clause

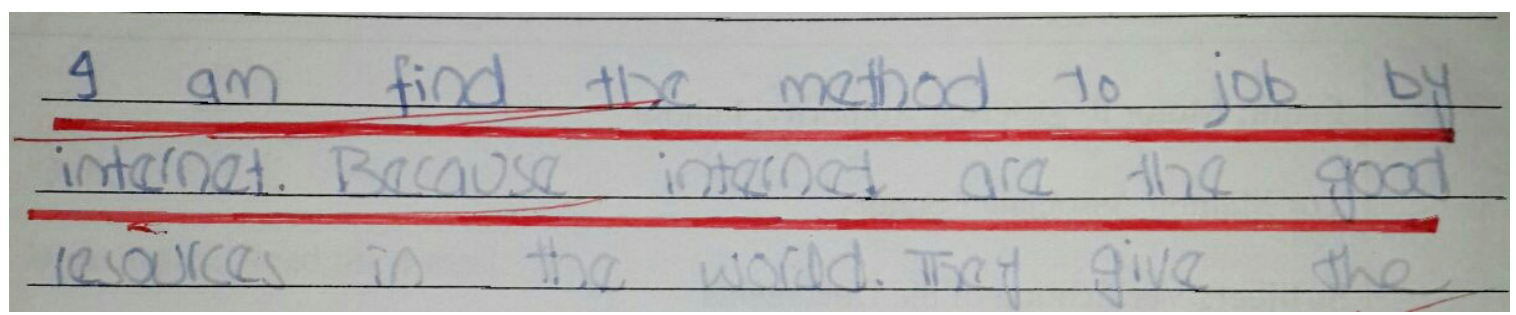

(17) Splitting Subordinate Clause

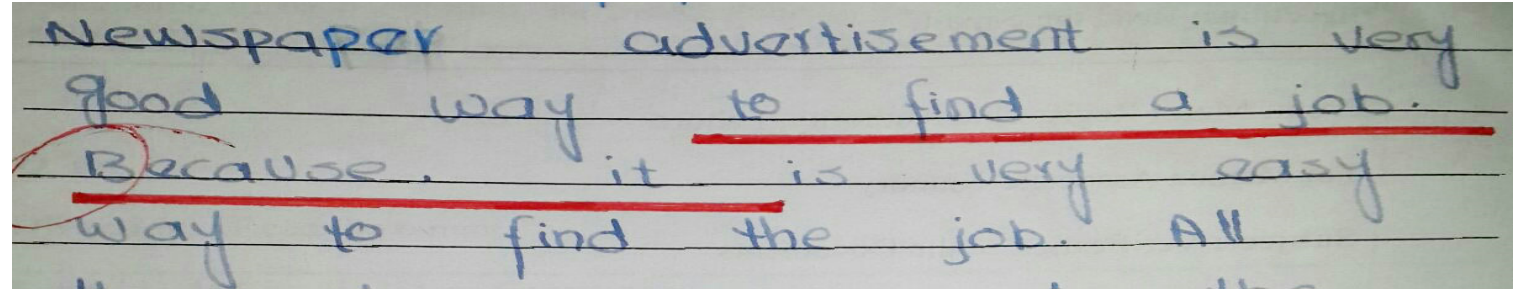

(18) Splitting Subordinate Clause

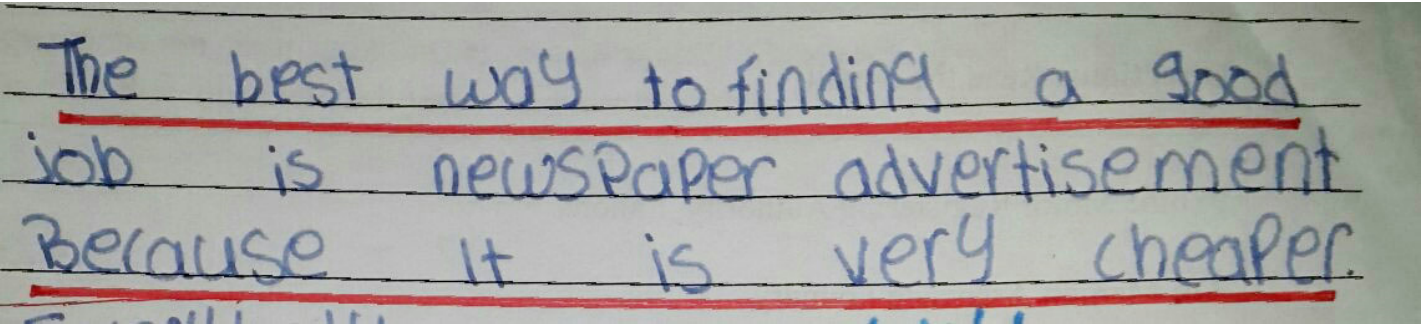

(19) Wrong Use of Condition Clause

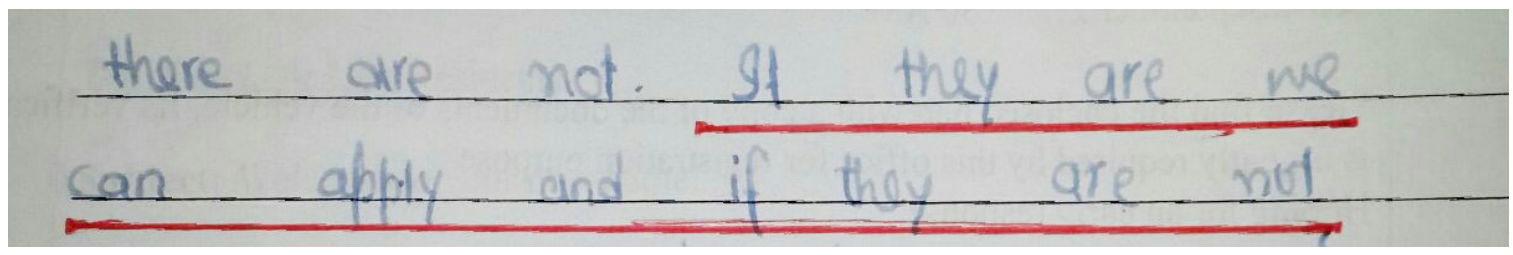

(20) Subjectless-Split Subordinate Clause

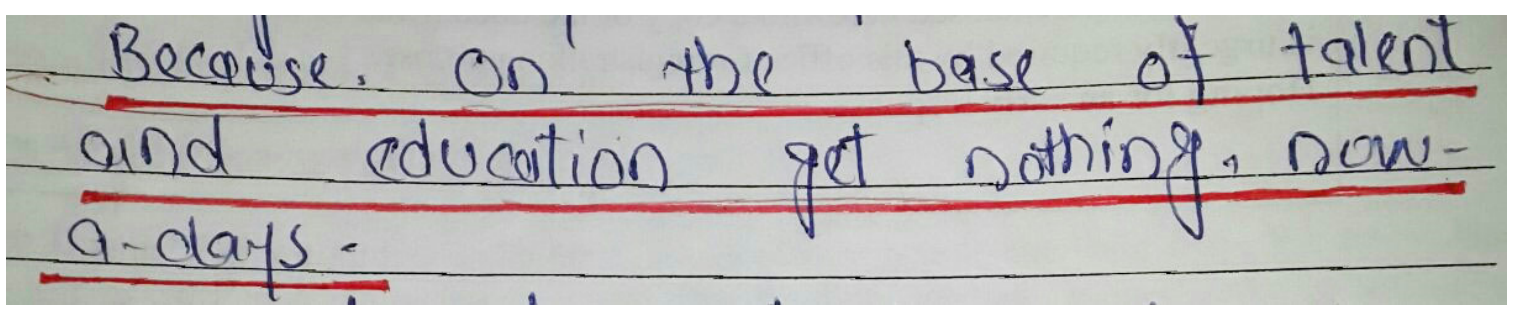

\section{Copyrights}

Copyright for this article is retained by the author(s), with first publication rights granted to the journal.

This is an open-access article distributed under the terms and conditions of the Creative Commons Attribution license (http://creativecommons.org/licenses/by/4.0/). 